\title{
Hatching period, growth and survival of young walleye pollock Theragra chalcogramma as determined from otolith analysis
}

\author{
Mary M. Yoklavich*, Kevin M. Bailey \\ Resource Assessment and Conservation Engineering Division, Alaska Fisheries Science Center, National Oceanic and \\ Atmospheric Administration, 7600 Sand Point Way NE, BIN C15700, Seattle, Washington 981 15-0700, USA
}

\begin{abstract}
Daily increments in otoliths were used to estimate growth rates and hatch dates of young walleye pollock Theragra chalcogramma from the western Gulf of Alaska, USA. Growth rate increased through the first $70 \mathrm{~d}$ after hatching and was described by a nonlinear, Laird-Gompertz model. There were no interannual differences in growth rates of young larvae from the limited size range collected in 1983 and 1985 to 1987 . Growth rates of older larvae and pelagic juveniles increased from southwest to northeast along the Alaskan Peninsula. Hatch dates were calculated from age of fish at time of collection; spawning dates were estimated after accounting for temperature-dependent egg stage duration. From 1983 to 1987 , spawning and hatch dates seem to have shifted to later in the season. This can indicate an overall change in time of spawning or increased removal, through mortality and dispersal, of eggs and larvae spawned early in the season. Hatch dates were earlier in the southwest near Unimak Island and later in the season to the northeast around Kodiak Island. Mortality was estimated from the difference in abundance of each daily cohort between the May and June-July surveys in 1987 and was age dependent. Mean daily instantaneous mortality rate was 0.11 for young larvae and decreased to 0.02 for older larvae and pelagic juveniles. From these rates, it is estimated that about $97 \%$ of the larvae will die or be removed from the Shelikof Strait area within $35 \mathrm{~d}$ of hatching.
\end{abstract}

\section{INTRODUCTION}

Survival and recruitment of young fishes depends on the combined action of biological and physical factors such as starvation, predation, larval transport, temperature, and turbulence. Larval size and growth are particularly important to the recruitment process because size is linked with resistance to starvation and predation (Miller et al. 1988), while small changes in growth rate and larval stage duration can cause significant interannual fluctuations in recruitment (Houde 1987).

Daily increments of otoliths provide a powerful tool to study growth and survival of larval and juvenile fishes. Increment counts have been used to estimate age of larval fish from the field (see review by Campana \& Neilson 1985); the resultant growth rates have been examined in terms of environmental (Methot \& Kramer 1979), geographical (Nishimura \& Yamada

\footnotetext{
- Present address: Moss Landing Marine Laboratories, PO Box 450, Moss Landing, California 95039, USA
}

1988), and interannual (Nyman \& Conover 1988, Warlen 1988) variability. Distributions of hatch dates, estimated from ages of larvae at the time of collection, can define periods of successful spawning relative to environmental conditions (Methot 1983, Checkley et al. 1988, Nyman \& Conover 1988). Successful spawning sites can be identified using rates and direction of ocean currents in conjunction with hatch dates. Survival of larval fish has been estimated from differences in hatch-date frequency distributions (Methot 1983, Essig \& Cole 1986, Rice et al. 1987).

In terms of biomass, walleye pollock Theragra chalcogramma has been the world's largest single-species commercial fishery since 1973 [Food and Agriculture Organization (FAO) 1974], with 1.6 million metric tons (t) harvested in 1986 in Alaskan waters (FAO 1988). Ichthyoplankton surveys conducted in the Shelikof Strait and surrounding areas of the western Gulf of Alaska since 1972 (Dunn \& Rugen 1989) have provided information on the early life history of walleye pollock (Kendall et al. 1987, Kim 1987). Most spawning is 
expected to occur during a 2 wk period from late March to early April in the deep water of Shelikof Strait. Eggs remain deep in the water column and hatch in approximately 2 wk at a depth of about $150 \mathrm{~m}$. Larvae begin to feed 5 to $6 \mathrm{~d}$ after hatching and then are found primarily in the upper $50 \mathrm{~m}$ of the water column where they are subject to transport by currents flowing toward the southwest at speeds from 5 to $30 \mathrm{~cm} \mathrm{~s}^{-1}$. Cohorts of eggs and larvae form large aggregations that can be followed both spatially and temporally for several weeks. Young-of-the-year juveniles inhabit areas downstream, along the continental shelf of the Alaskan Peninsula (Hinckley et al. 1989). These circumstances provide a unique opportunity to assess rates of growth and mortality during the early life of this species.

Using age and hatch-date distributions derived from otoliths of young walleye pollock collected in the Shelikof Strait and surrounding areas, our objectives were (1) to describe the growth rate throughout early life, (2) to assess interannual and geographical differences in growth rates and in successful spawning dates, and (3) to estimate mortality.

\section{METHODS}

Larval and juvenile collections. Young walleye pollock larvae $(<46$ d old) were collected during ichthyoplankton surveys in the Shelikof Strait region of the western Gulf of Alaska in May of 1983 and 1985 to 1987. Collection techniques followed Kendall et al. (1987); briefly, samples were taken with a doubleoblique tow using a $60 \mathrm{~cm}$ bongo net (333 or $505 \mu \mathrm{m}$ mesh). In 1987, older larval and pelagic juvenile walleye pollock (from 36 to 85 d old) were collected at 148 stations throughout the western Gulf of Alaska, beginning near Unimak Island on 18 June and terminating northeast of Kodiak Island on 16 July. Fish were sampled using a $5 \mathrm{~m}^{2}$ Methot frame trawl (Methot 1986) equipped with oval mesh $(2 \times 3 \mathrm{~mm})$. The net was deployed from the NOAA ship 'Miller Freeman' and retrieved obliquely from a maximum depth of $300 \mathrm{~m}$ (Hinckley et al. 1989). Subsamples of fish were preserved in $95 \%$ buffered ethanol for otolith examination.

For each survey, the number of fish per tow was standardized to number under $10 \mathrm{~m}^{2}$ of sea surface. Standard length ( $\mathrm{SL}$, to the nearest $0.1 \mathrm{~mm}$ ) was measured from random subsamples of formalin-preserved fish taken at each station. Length distributions were expanded to the total catch at each station. Size was not corrected for possible shrinkage due to collection or fixation techniques.

Age and growth determination. In May 1983, larvae were collected for age and growth determination from
5 locations, including the area of highest larval abundance (Fig. 1A). Limited numbers of larvae were collected for ageing studies in May 1985 and 1986 (Fig. $1 \mathrm{~B}, \mathrm{C})$. Larvae were obtained for age analysis from 13 stations throughout the survey area in May 1987 (Fig. 1D). Otoliths were removed and SL (to the nearest $0.1 \mathrm{~mm}$ ) was measured from fish of the entire range of sizes within each sample.

Otolith increment deposition is daily for larval and juvenile walleye pollock to at least $100 \mathrm{~d}$, with a welldefined increment formed at hatching (Nishimura \& Yamada 1984, Bailey \& Stehr 1988). Age was determined using techniques reported in Kendall et al. (1987). The ages of larvae from the 1983 samples have been previously reported in Kendall et al. (1987).

Age and growth were determined for older larvae and pelagic juveniles from Unimak Island to Kodiak Island, including fish from the area of highest density, between the Semidi and Shumigin Islands (Fig. 2). Both sagittae were removed, and thin sections in the sagittal plane were prepared for age determination, using techniques described by Boehlert \& Yoklavich (1985). Otolith sections were covered with immersion oil, and growth increments were counted at $1000 \times$ magnification using a compound microscope and transmitted light. In most cases, both otoliths from each fish were examined and the higher number of increments was used to estimate age. Most increment widths were greater than $1 \mu \mathrm{m}$, and groups of narrowly spaced increments having widths below the theoretical limits of resolution by light microscopy [calculated by Campana et al. (1987) to be $0.2 \mu \mathrm{m}$ ] were not evident. Increment counts from otoliths from a broad size range of larvae were confirmed by a second reader.

Age and length data from young larvae were plotted over all stations within each survey to determine growth rates and hatch dates. Preliminary examination of the otoliths of the older larvae and pelagic juveniles collected in June and July 1987 indicated that increment widths were narrower in otoliths from the southwest near Unimak Island and wider in otoliths from the northeast around Kodiak Island, suggesting possible differences in larval growth between locations. We therefore separated the data into 3 areas: (1) stations located off Unimak Island at the most southwest point of the survey; (2) stations between the Semidi and Shumigin Islands, representing the area of highest fish abundance; and (3) stations around Kodiak Island (Fig. 2).

Hatch-date distributions. Hatch dates were estimated from age and date of capture. Length-frequency distributions, representing total, standardized abundances of fish at each station, were converted to age using separate age-length keys (Kimura 1977) developed from subsamples of fish at selected stations 

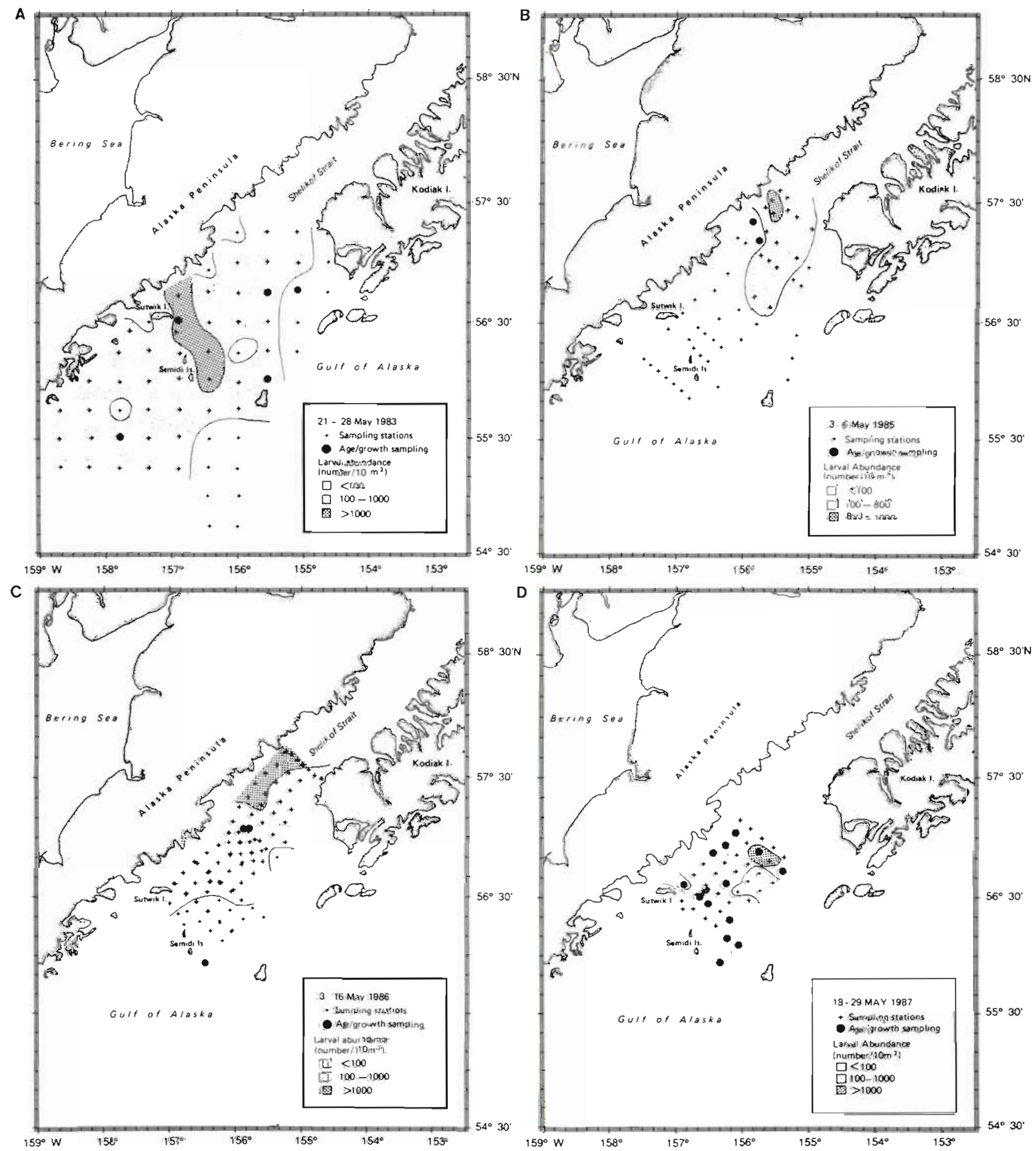

Fig. 1. Locations of larval walleye pollock collections in the western Gulf of Alaska during May of (A) 1983, (B) 1985, (C) 1986, and (D) 1987

within each survey and for each of the 3 areas within the June-July 1987 survey. Hatch-date distributions were generated from these computed age distributions.

For seasonal and interannual comparisons, hatchdate distributions were corrected for mortality because fish that hatched closer to the time of collection experienced less mortality than older fish in the samples. Size-specific mortality rates of larval and juvenile walleye pollock were unknown a priori. We therefore combined field mortality rates for small walleye pollock 


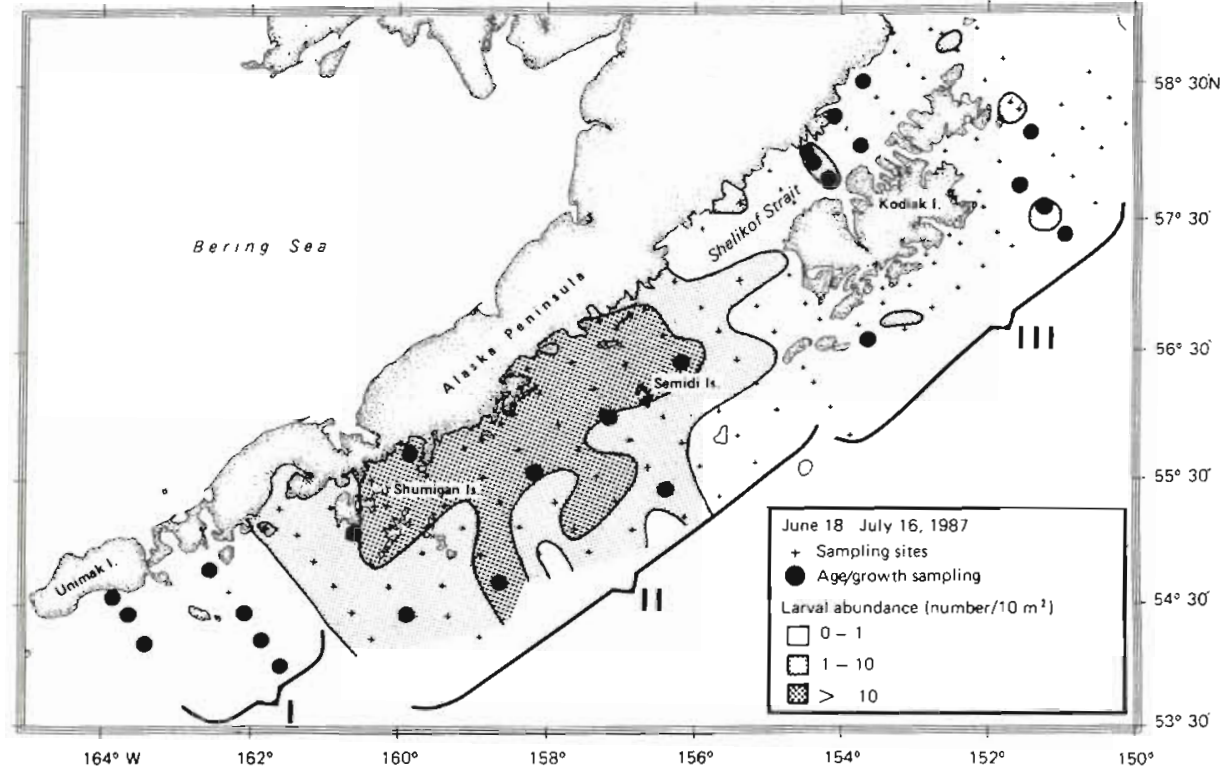

Fig. 2. Locations of sampling sites of older walleye pollock larvae and pelagic juveniles in the western Gulf of Alaska during June and July 1987. Areas used in geographic comparisons of growth rates and hatch dates are designated I, II, and I!! larvae, ranging from $0.096 \mathrm{~d}^{-1}$ for larvae 4 to $5 \mathrm{~mm} \mathrm{SL}$ and $0.082 \mathrm{~d}^{-1}$ for larvae 8 to $9 \mathrm{~mm} \mathrm{SL}$ (Kim 1987) to $0.062 \mathrm{~d}^{-1}$ for larvae less than $15 \mathrm{~mm}$ SL (Reed et al. 1989), with those for larger marine fish larvae calcuIN RUHEated from a general equation of mortality on weight reported by McGurk (1986), and a lengthweight relationship for larval walleye pollock (Bailey \& Stehr 1986). A stepped size-specific mortality function was created, with rates of: $0.10,0.08,0.06,0.03$, $0.01 \mathrm{~d}^{-1}$ for fish $4-7,7.1-10,10.1-15,15.1-20$ and 20.1-30 $\mathrm{mm} \mathrm{SL}$, respectively. The range of ages corresponding to each mortality rate was calculated from our 1987 growth equation. This age-specific mortality correction generally resulted in a redistribution of hatch date frequencies, especially in those collections with the widest ranges of ages (i.e. from 1983 and 1987).

Mortality estimates. Daily instantaneous mortality rates were calculated from the difference in the abundance of each daily cohort between the May and June 1987 surveys. Note that these estimates were not corrected with the size-selective mortality function mentioned in the previous section. Abundance was adjusted beforehand using the Sette-Ahlstrom census method (Richardson 1981) in which the number of fish under $10 \mathrm{~m}^{2}$ of sea surface was weighted by the area represented by each station. Mortality rates $\left(Z_{i}\right)$ were calculated as:

$$
\mathrm{Z}_{\mathrm{i}}=-\left[\log _{\mathrm{e}}\left(\mathrm{N}_{\mathrm{J}_{\mathrm{i}}} / \mathrm{N}_{\mathrm{M}_{\mathrm{i}}}\right)\right] \mathrm{t}^{-1}
$$

where $N_{J_{1}}$ is the number of fish collected in June that hatched on Day $i_{i} N_{M_{i}}$ is the number of fish collected in May that hatched on Day $i_{i}$ and $t=38 \mathrm{~d}$ (the time interval between median dates of each survey).

\section{RESULTS}

\section{Age and growth}

Ages of 638 larval and pelagic juvenile walleye pollock from the western Gulf of Alaska ranged from 3 to $85 \mathrm{~d}$ (Table 1). From the 1987 collections, 357 young walleye pollock were considered for intra-annual assessment of age and growth throughout early development. These included 204 larvae 13.9 to $11.2 \mathrm{~mm}$ SL) from the May collections and 153 older larvae and pelagic juveniles (12.8 to $30.0 \mathrm{~mm} \mathrm{SL}$ ) from the June and July collections in Area II. Otolith increment counts (days since hatching) ranged from 3 to 34 for the larvae collected in May, and from 36 to 66 for the older fish.

Estimated age and length data from the May and June-July 1987 (Area II only) collections were combined and growth was described with a nonlinear Laird-Gompertz function, using Marquardt's algorithm as implemented in SYSTAT (Wilkinson 1987):

$$
L_{t}=4.505\left[e^{7.854\left(1-e^{-0.000 t} t\right)}\right]
$$

where $\mathrm{L}_{\mathrm{t}}=$ standard length $(\mathrm{mm}$ ) at age $\mathrm{t}$ (days from hatch; Fig. 3). An approximate coefficient of determination $\left(r^{2}\right)$ is 0.95 . The model suggests that growth rate of young walleye pollock is relatively slow to an age of about $20 \mathrm{~d}$, with a mean absolute growth rate of about $0.16 \mathrm{~mm} \mathrm{~d}^{-1}$ during the first $10 \mathrm{~d}$ post-hatching; growth rate accelerates with age to about $0.66 \mathrm{~mm} \mathrm{~d}^{-1}$ for 60 to 70 -d-old fish. Larval length at time of hatching was estimated by the model to be $4.5 \mathrm{~mm}$, which approximates the mean length of live walleye pollock hatched 
Table 1. Theragra chalcogramma. Information on larval and juvenile collections in the western Gulf of Alaska. Values in parentheses are percentages; age and length ranges given

\begin{tabular}{|c|c|c|c|c|c|}
\hline \multirow[t]{2}{*}{ Collection date } & \multirow[t]{2}{*}{ No. caught } & \multirow[t]{2}{*}{ No. measured } & \multirow[t]{2}{*}{ No. aged } & \multicolumn{2}{|c|}{ Aged specimens } \\
\hline & & & & Age (d) & Length (mm) \\
\hline 21-28 May 1983 & 4136 & $1919(47)$ & $109(3)$ & $7-46$ & $6.0-14.7$ \\
\hline 1-12 May 1985 & 321 & $258(80)$ & $25(8)$ & $6-23$ & $5.8-9.0$ \\
\hline 3-16 May 1986 & 12803 & $4239(33)$ & $76(0.6)$ & $3-14$ & $5.2-8.7$ \\
\hline 18-29 May 1987 & 2571 & $1740(68)$ & $204(8)$ & $3-34$ & $3.9-11.2$ \\
\hline $\begin{array}{l}\text { 18-19 Jun } 1987 \\
\text { (Area I) }\end{array}$ & 37 & $34(92)$ & $36(97)$ & $39-75$ & $12.9-25.7$ \\
\hline $\begin{array}{l}19 \text { Jun-10 Jul } 1987 \\
\text { (Area II) }\end{array}$ & 4699 & $1729(37)$ & $153(3)$ & $36-66$ & $12.8-30.0$ \\
\hline $\begin{array}{l}\text { 10-15 Jul } 1987 \\
\text { (Area III) }\end{array}$ & 95 & $86(91)$ & $35(37)$ & $42-85$ & $16.8-40.8$ \\
\hline
\end{tabular}

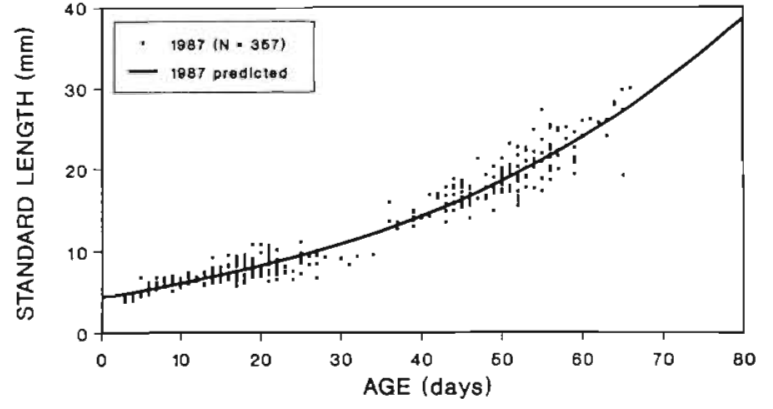

Fig. 3. Theragra chalcogramma. Estimated age versus length for larval and juvenile walleye pollock collected in May and June-July 1987 (only Area II). The line represents a leastsquares fit of the Laird-Gompertz growth model: $\mathrm{L}_{\mathrm{q}}=$ $4.505 \mathrm{e}^{7.854\left(1-e^{-0.004}\right)}$

in the laboratory from eggs collected in the study area (4.3 mm SL; M. Yoklavich unpubl.).

A least-squares linear model, length $=a+b$ (age), was fitted to each of the 4 sets of age-length data from the years 1983 and 1985 to 1987 , over the limited range of ages common to all sets. A linear model was used to facilitate interannual growth rate comparisons and adequately fit the data because of the narrow age ranges. No differences in growth rates were found (analysis of covariance i.e. ANCOVA, p >0.078). Sample sizes were small because of narrow ranges in age of the 1985 and 1986 fish (Table 1). A comparison of the data sets with the broadest ranges of ages, those collected in 1983 [a year of relatively high walleye pollock spawning biomass (Megrey 1989)] and those from 1987 (a year of low spawning biomass), also indicated no difference in growth rate over common ages ( 7 to $25 \mathrm{~d}$; ANCOVA, $p>0.703$ ). In all possible pairwise comparisons among the 4 years of data, using those ages common to each comparison, there were no differences in growth rates.

Growth rates were assessed for older larvae and pelagic juveniles collected in June and July 1987 from the 3 areas described earlier (Fig. 4). A least-squares linear model was used to describe growth from the 3 sets of age and length data, over those ages (42 to 66 dold) common to all areas. Although Areas I and III represent fewer fish, significant (ANCOVA, p < 0.001)

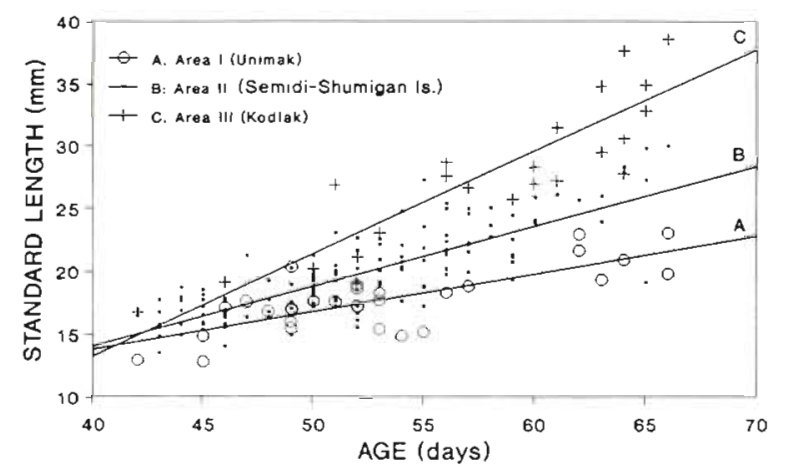

Fig. 4. Theragra chalcogramma. Growth of walleye pollock collected in June and July 1987. Regression models relating length ( $\mathrm{L}$ ) and age (a) are $(\mathrm{A}) \mathrm{L}=1.81+0.30 \mathrm{a}, \mathrm{r}^{2}=0.59, \mathrm{~N}=$ 31; (B) $\mathrm{L}=0.48 \mathrm{a}-4.92, \mathrm{r}^{2}=0.66, \mathrm{~N}=139$; and (C) $\mathrm{L}=0.82 \mathrm{a}$

$$
-19.24, r^{2}=0.78, N=24
$$

differences were found among areas; mean absolute growth rate was slowest $\left(0.30 \mathrm{~mm} \mathrm{~d}^{-1}\right)$ in the southwest and increased to the north with mean rates of $0.48 \mathrm{~mm}$ $\mathrm{d}^{-1}$ in the main aggregation and $0.82 \mathrm{~mm} \mathrm{~d}^{-1}$ from fish collected near Kodiak Island.

\section{Hatch-date distributions}

Hatch-date distributions were compared between early larvae collected in May 1987 and the older fish collected from Area II in June and July 1987 (Fig. 5). Both distributions have similar ranges of hatch dates (16 April to 24 May and 7 April to 26 May, respectively) and comparable median hatch dates (i.e. 2 May and 


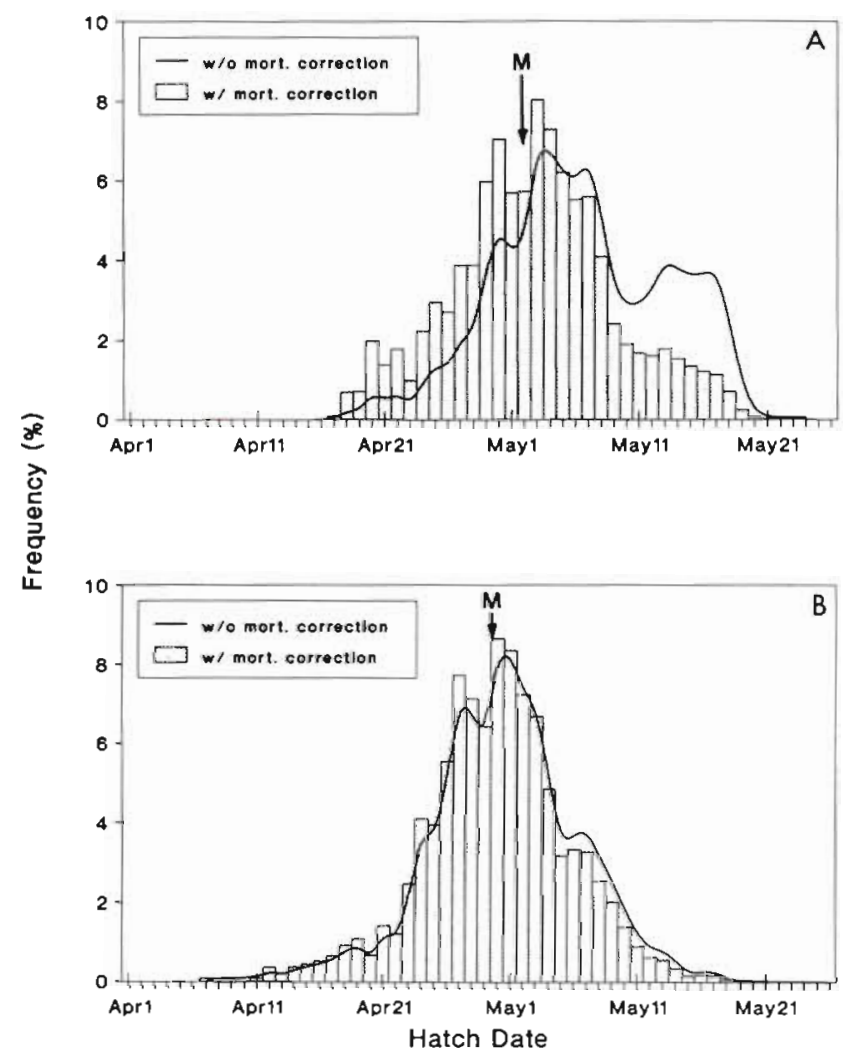

Fig. 5. Theragra chalcogramma. Hatch date distributions estimated from age of walleye pollock collected in (A) May 1987 and (B) June-July 1987. Bars represent frequencies corrected for differential mortality (i.e. w/mort. correction; see text); continuous lines are the frequency distributions without mortality corrections (i.e. w/o mort. correction). Median dates (M) are also indicated

29-30 April, respectively, from distributions with mortality corrections), supporting the contention that they represent the same cohort of spawned eggs. There is a noticeable decrease, however, in the relative number of fish hatched late in the season, with $58 \%$ of the fish collected in May hatching after 1 May, and only $37.5 \%$ of the older larvae collected in June and July having hatch dates after this date $(77$ and $42 \%$, respectively, from distributions without mortality corrections).

A distinct shift toward later hatch dates for walleye pollock collected in May is evident over the 4 years considered (Fig. 6). This trend is demonstrated in the delayed median hatch dates and increased percentage of larvae in the 1986 and 1987 collections that hatched after 1 May (Table 2).

Median spawning dates were estimated from the hatch dates and egg incubation period (Table 2). Duration of the egg stage depends upon bottom water temperature in Shelikof Strait in March and April and was calculated from the relation between temperature and hatching-time reported by Haynes \& Ignell (1983).
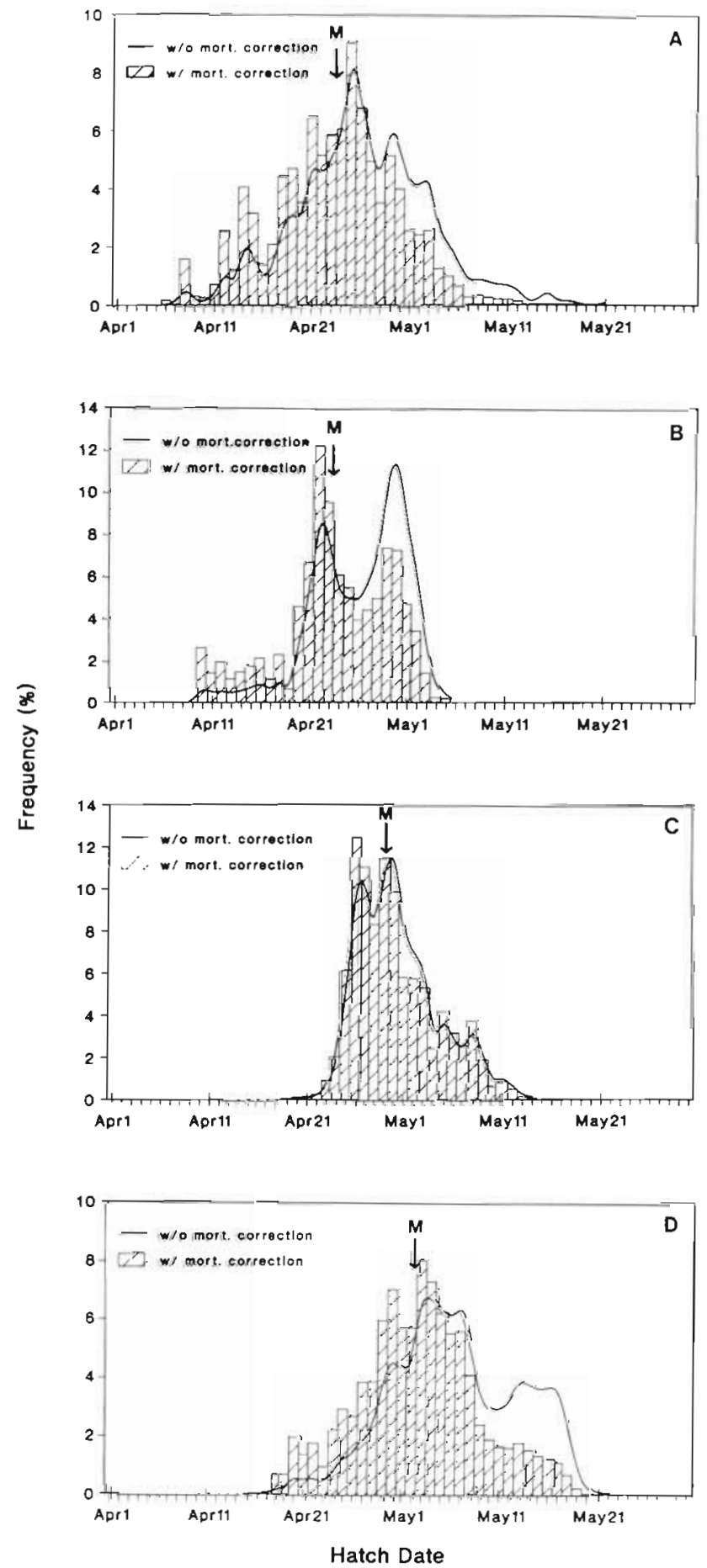

Fig. 6. Theragra chalcogramma. Hatch date distributions, based upon age, of young walleye pollock collected in May (A) 1983, (B) 1985, (C) 1986, and (D) 1987. See Fig. 5 for further details

Egg surveys conducted in Shelikof Strait describe peak spawning time as the first week in April, with continued spawning of less intensity through May (Kim 1987). Peak spawning in 1983 and 1985, predicted from 
Table 2. Theragra chalcogramma. Median spawning $\left(\mathrm{M}_{\mathrm{S}}\right)$ and hatch $\left(\mathrm{M}_{\mathrm{H}}\right)$ dates for larvae collected during May in the western Gulf of Alaska

\begin{tabular}{|crrrrr|}
\hline Year & MS & M & $\begin{array}{c}\text { \% hatch } \\
\text { after May 1 }\end{array}$ & $\begin{array}{c}\text { Days to } \\
\text { hatch }\end{array}$ & $\begin{array}{c}\text { Bottom temp. } \\
\left({ }^{\circ} \mathrm{C}\right)^{\mathrm{a}}\end{array}$ \\
\hline 1983 & $10 \mathrm{Apr}$ & $23 \mathrm{Apr}$ & 10 & 13 & 5.5 \\
1985 & $9 \mathrm{Apr}$ & $23 \mathrm{Apr}$ & 5 & 14 & 5.3 \\
1986 & $15 \mathrm{Apr}$ & $29 \mathrm{Apr}$ & 32 & 14 & 5.0 \\
1987 & $20 \mathrm{Apr}$ & $2 \mathrm{May}$ & 58 & & 5.6 \\
a J. Schumacher unpubl. & & & & & \\
\hline
\end{tabular}

age of larvae, was comparable to that expected from egg surveys. The median spawning date predicted for 1986 was nearly a week later. In 1987, the median spawning date, predicted from the ages of surviving larvae, was 20 April.

Hatch-date distributions estimated from ages of the larvae collected in June and July 1987 indicated earlier hatching in the southwest near Unimak Island (median date of 25 April) and later hatching to northeast around Kodiak Island (median date of 8 May; Fig. 7). Distributions from these 2 areas appeared multi-modal. Eight percent of the larvae collected in Area I had hatch dates in late March, $37 \%$ represented hatching in early April, and $55 \%$ hatched in late April or early May (Fig. 7C). Sixty-eight percent of the larvae found in Area III hatched from 24 April to 14 May; smaller amounts of hatching occurred in mid-April $(8 \%)$ and late May (24\%; Fig. 7A).

\section{Mortality}

Daily instantaneous mortality rates, calculated from the difference in area-adjusted hatch date distributions between the May and June-July surveys in 1987. increased throughout the hatching period (Fig. 8). Mortality rate appears to be a function of age and size of the fish at capture. For example, the highest mortality rates, averaging 10 to $11 \% \mathrm{~d}^{-1}$, were experienced by the youngest larvae whose hatch dates were nearest to the date of collection (Table 3). Mortality rate decreased steadily with increased length and age of larvae. Cumulative larval mortality during the first $35 \mathrm{~d}$ was estimated at about $93 \%$.

\section{DISCUSSION}

Our otolith data, combined with the opportunity to track aggregations of walleye pollock larvae through time in the Alaska Coastal Current, allow us to make realistic estimates of growth and mortality during the early life of this species. These estimates will make possible the assessment of interannual variability in early survival and its role in recruitment of walleye pollock stocks. In the broader context of marine ecology, the ability to make precise estimates of growth and mortality by ageing larval fish from otoliths is unparalleled in other planktonic organisms, and can be useful in the analysis of size-scaled processes of marine organisms (Peterson \& Wroblewski 1984).

Growth rates of larval walleye pollock based on otolith analysis increase throughout the first $70 \mathrm{~d}$ posthatching. Most larval walleye pollock are concentrated between 15 and $50 \mathrm{~m}$ in Shelikof Strait (Kendall et al. 1987). Because water temperature in the upper $50 \mathrm{~m}$ of our survey area increased from around $5^{\circ} \mathrm{C}$ during the larval stage to over $8^{\circ} \mathrm{C}$ during the early juvenile period (J. Schumacher unpubl.), it is difficult to discriminate between the effects of temperature and developmental stage on growth rate. With appropriate temperature records collected during early larval development each year, an age- and temperaturebased growth model similar to that recently developed for cod (Gadus morhua) and haddock (Melanogrammus aeglefinus) larvae in the Gulf of Maine (Campana \& Hurley 1989) could be applied to future growth studies of walleye pollock larvae in the Gulf of Alaska. In general, mean water temperature at $50 \mathrm{~m}$ depth in Shelikof Strait was similar in May of 1983, 1985, and $1987\left(5\right.$ to $\left.6^{\circ} \mathrm{C}\right)$. Although mean water temperature at $50 \mathrm{~m}$ in May of 1986 was relatively cold $\left(3.3^{\circ} \mathrm{C}\right.$; J. Schumacher unpubl.), the growth rate of young larvae collected downstream from Shelikof Strait did not differ significantly from rates in the other years.

Our growth rates are comparable to those estimated for walleye pollock larvae of the same age held in the laboratory at 9 to $11^{\circ} \mathrm{C}$ with abundant food (Bailey \& Stehr 1986). This suggests that surviving larvae obtain enough food in the field for adequate growth. Yamashita \& Bailey (1989) reported high mortality rates for young larvae held in low prey densities during the first-feeding transition, indicating that larvae exposed to episodic food limitations may not survive to be sampled in the field. Growth rates similar to ours also were 

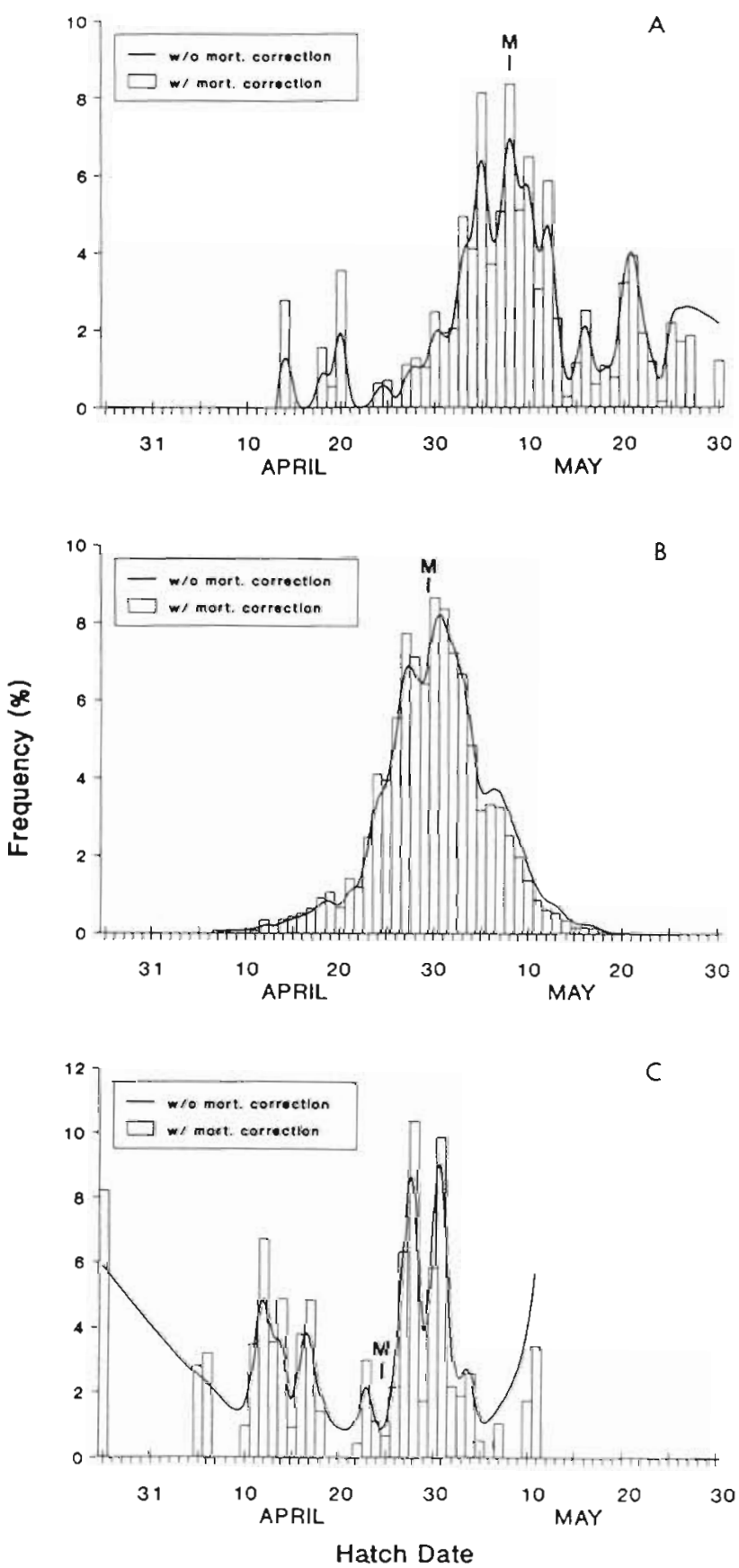

Fig. 7. Theragra chalcogramma. Hatch date distributions, based upon age of older larvae and juveniles of walleye pollock collected in June-July 1987 (A) near Kodiak Island, (B) between the Semidi and Shumigin Islands, and (C) near Unimak Island. See Fig. 5 for further details

reported for larval and juvenile walleye pollock collected from the waters around Hokkaido, Japan (Nishimura \& Yamada 1984, 1988).

Density-dependent larval growth is considered one of the likely causes of the asymptotic relationship between recruitment and the parent stock (Shepherd \&

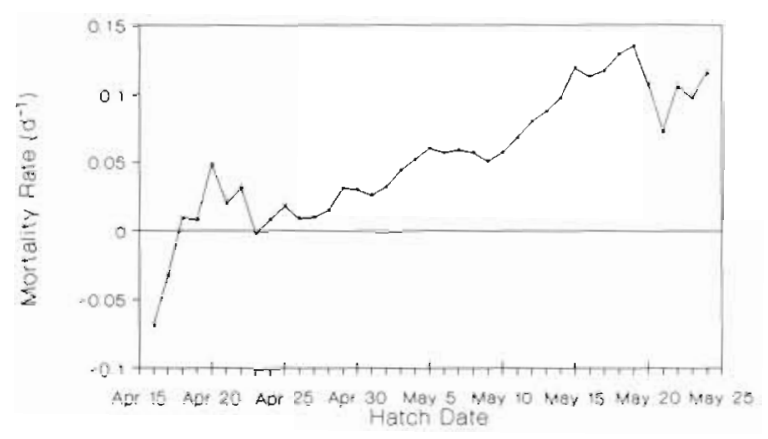

Fig. 8. Theragra chalcogramma. Instantaneous daily mortality rates by hatch date for larval walleye pollock in the western Gulf of Alaska

Cushing 1980). Although an asymptotic or domeshaped stock-recruitment relationship has been observed for walleye pollock in the western Gulf of Alaska (Megrey 1989), we found no evidence of density-dependent growth of young larvae. Adult biomass of walleye pollock in the Shelikof Strait region, estimated from hydroacoustic and bottom trawl surveys, has declined continually from a peak of $3.4 \times 10^{6} \mathrm{t}$ in 1981 to $2.2 \times 10^{6} \mathrm{t}$ in 1983 and about $0.3 \times 10^{6} \mathrm{t}$ in 1988 (Megrey 1989). A general decline in larval abundance also is apparent from 1981 to 1987 (from about $10 \times 10^{11}$ to $3.8 \times 10^{11}$ larvae; S. Picquelle pers. comm., K. Bailey unpubl.), although comparisons are difficult considering potential differences in larval age and survey dates. The lack of interannual differences among growth rates for 1983 and 1985 to 1987 does not support the density-dependent growth hypothesis for walleye pollock larvae.

Although interannual differences in growth were not discerned for young larvae, the potential for spatial and temporal variation in growth was demonstrated for older larvae and pelagic juveniles. Growth rates increased significantly from southwest to northeast along the Alaska Peninsula. Collections were initiated in June in the southwest and terminated in mid-July in the northeast; water temperature in the upper $50 \mathrm{~m}$ increased from about $5^{\circ} \mathrm{C}$ in mid-June to over $8^{\circ} \mathrm{C}$ in early July (J. Schumacher unpubl.). Nishimura \& Yamada (1988) reported a marked increase in growth for young walleye pollock hatched later in the season in the Okhotsk Sea and suggested that rapid growth may correspond to increasing water temperature during larval development.

Changes in time of spawning can contribute to variations in year-class abundance by influencing the spatial and temporal coincidence of larvae, prey availability, predator abundance, and favorable environmental conditions, such as temperature and upwelling (Cushing 1975, Parrish et al. 1981). Median spawning and hatch dates of surviving walleye pollock larvae differ 
Table 3. Theragra chalcogramma. Mean daily instantaneous mortality coefficients (Z) estimated from hatch date distributions of larval walleye pollock from the May and June 1987 surveys. Mean (and range) in length and age of larvae of time of capture are reported by hatch date

\begin{tabular}{|c|c|c|c|c|c|c|}
\hline \multirow[t]{2}{*}{ Hatch date } & \multicolumn{2}{|c|}{ May } & \multicolumn{2}{|c|}{ June } & \multirow[t]{2}{*}{ z } & \multirow{2}{*}{$\begin{array}{l}\text { Percent mortality } \\
\qquad\left(d^{-1}\right)\end{array}$} \\
\hline & Size $(\mathrm{mm})$ & Age $(d)$ & Size $(\mathrm{mm})$ & Age (d) & & \\
\hline 16-19 Apr & $\begin{array}{c}10 \\
(8-13)\end{array}$ & $\begin{array}{c}33 \\
(31-39)\end{array}$ & $\begin{array}{c}26 \\
(19-39)\end{array}$ & $\begin{array}{c}65 \\
(63-80)\end{array}$ & -0.02 & -2.1 \\
\hline $20-27 \mathrm{Apr}$ & $\begin{array}{c}9 \\
(7-13)\end{array}$ & $\begin{array}{c}28 \\
(23-27)\end{array}$ & $\begin{array}{c}23 \\
(17-36)\end{array}$ & $\begin{array}{c}60 \\
(53-77)\end{array}$ & 0.02 & 1.8 \\
\hline 28 Apr-6 May & $\begin{array}{c}8 \\
(6-11)\end{array}$ & $\begin{array}{c}19 \\
(14-28)\end{array}$ & $\begin{array}{c}21 \\
(15-34)\end{array}$ & $\begin{array}{c}53 \\
(44-74)\end{array}$ & 0.04 & 3.9 \\
\hline 7-10 May & $\begin{array}{c}7 \\
(6-10)\end{array}$ & $\begin{array}{c}14 \\
(10-20)\end{array}$ & $\begin{array}{c}19 \\
(14-30)\end{array}$ & $\begin{array}{c}45 \\
(40-65)\end{array}$ & 0.06 & 5.5 \\
\hline 11-15 May & $\begin{array}{c}6 \\
(5-10)\end{array}$ & $\begin{array}{c}8 \\
(5-16)\end{array}$ & $\begin{array}{c}17 \\
(13-27)\end{array}$ & $\begin{array}{c}42 \\
(36-61)\end{array}$ & 0.09 & 8.7 \\
\hline 16-22 May & $\begin{array}{c}5 \\
(4-7)\end{array}$ & $\begin{array}{c}4 \\
(3-11)\end{array}$ & $\begin{array}{c}16 \\
(12-25)\end{array}$ & $\begin{array}{c}40 \\
(33-56)\end{array}$ & 0.11 & 10.6 \\
\hline 23-24 May & $\begin{array}{c}4 \\
(4-5)\end{array}$ & $\begin{array}{c}4 \\
(3-4)\end{array}$ & $\begin{array}{c}16 \\
(15-19)\end{array}$ & $\begin{array}{c}48 \\
(45-49)\end{array}$ & 0.11 & 10.2 \\
\hline
\end{tabular}

interannually by about $2 \mathrm{wk}$, and in recent years have progressively shifted to later in the season. Although larvae were sampled earlier in the season in 1985 and 1986 (Table 1), and from more limited areas of their distribution (Fig. 1), the hatch-date distributions from these years are consistent with the trend established from age data in 1983 and 1987 (years of comparable sampling dates and areal representation).

The mortality corrections that we implemented in the hatch date analysis are approximations based on available data. These corrections realistically could be underestimated by as much as a factor of 2 (errors associated with measurements of mortality are discussed later). A simple simulation with double mortality corrections for all age groups in both 1987 surveys (i.e. May and June-July) resulted in median hatch dates similar to the original corrected distributions. However, this simulation did redistribute the hatch dates from the May survey, thereby reducing the number of larvae hatched late in the season and producing a distribution closer to that of the June-July survey. This indicates that our mortality correction factors likely were conservative, especially for the young age groups.

Hatch-date distributions were used to examine transport and mortality of larvae. Current speeds in the Shelikof Strait region typically vary from 5 to $30 \mathrm{~cm} \mathrm{~s}^{-1}$ during the months when walleye pollock eggs and larvae are present; the more vigorous southwestward flow occurs in the Alaska Coastal Current, while weak and sometimes reversed flow is found along the Alaska Peninsula (Incze et al. 1989). The marked down-current progression of earlier larval hatch distributions from the June-July 1987 survey (Fig. 7) is indicative of significant southwestward advection of eggs and younger larvae spawned in the Shelikof Strait. Earliest hatch dates were observed for larvae collected near Unimak Island, an area farthest from the proposed spawning site near Cape Kekurnoi. The fast-growing larvae collected around Kodiak Island were most recently spawned ( $82 \%$ after 15 April).

The similarity in hatch distributions of larvae collected from the main aggregations in May 1987 and June-July 1987 (Fig. 5) indicates that the 2 surveys sampled the same larval cohort. Furthermore, the median age of larvae from the May collection is $16 \mathrm{~d}$; median age of older larvae collected in June and July is $54 \mathrm{~d}$. The difference in median age of the 2 groups of larvae is $38 \mathrm{~d}$ and equal to the interval of time between median sampling dates of the 2 surveys. The centers of abundance for these 2 collections are about $200 \mathrm{~km}$ apart, suggesting a larval transport rate of about $5 \mathrm{~km}$ $\mathrm{d}^{-1}$. This is considered to be a moderate current speed in this area of the Gulf at this time of year (Incze et al. 1989), and demonstrates the likelihood that the aggregation of larvae collected early in the season northeast of the Semidi Islands is the same cohort of older larvae found along the Alaskan Peninsula in June and July. The movement of satellite-tracked drifters, drogued at $40 \mathrm{~m}$ and released in the main spawning area in April 1987, also supports the assumption that the May and June-July aggregations represent the same cohort (Hinckley et al. 1989).

Assumptions in our assessment of mortality are that diffusion of larvae is not influencing the estimate of total abundance, and that coverage of the area of each daily cohort's distribution is complete in both surveys. Although eddy diffusivity can be important in this area, it is probably compensated to varying degrees by hori- 
zontal convergence (Reed et al. 1989). Furthermore, sampling a much broader area during the June-July survey should account for surviving larvae from the May survey, thereby reducing possible effects of advective or diffusive losses from the sampling boundary. The downstream increase in larval age and the observance that fish at the most southwest area of the June-July survey hatched earlier than those in the May survey further indicates that the larvae surveyed in May were encompassed by the later survey.

The absence of a clear gradient of larval concentrations outside the area of highest abundance during the early survey (Fig. 1D) suggests incomplete sampling, most likely of the older larvae that have drifted from the center of spawning activity. Underestimating the number of older larvae during the May survey leads to negative mortality rates for larvae ( 8 to $13 \mathrm{~mm}$ ) with the earliest hatch dates (Fig. 8, Table 3). Along with possible dispersal of the oldest larvae from the May survey, avoidance of the bongo nets by the largest larvae sampled during May could also contribute to the negative mortality rates for the oldest fish. However, comparisons of length frequencies of larval walleye pollock between day and night and between $1 \mathrm{~m}$ Tucker trawl and $60 \mathrm{~cm}$ bongo samples did not indicate size-selective avoidance (Kendall et al. 1987). The variable mortality rates among the smallest larvae hatched after 20 May (Fig. 8) indicate under-representation of this group in the May survey, possibly due to extrusion of some yolk-sac larvae from the $505 \mu \mathrm{m}$ mesh bongo nets. Our future analyses of data from 1988 and 1989 ichthyoplankton surveys will yield more precise estimates of larval mortality and the combined effects of advection, eddy diffusivity, and horizontal convergence. Our values of average daily mortality occurring in the interim between the 2 surveys are comparable to those estimated for aggregated sizes of young larval walleye pollock collected in Shelikof Strait (Kim 1987. Reed et al. 1989), as well as for other gadid species of the same early life stages (Gamble \& Houde 1984, Houde 1987). Although our estimates of mortality were relatively high during the earliest larval stages, they were much lower than those predicted by McGurk's (1986) general equation based on larval dry weight [e.g. from $1.31 \mathrm{~d}^{-1}$ for larvae at $36.1 \mu \mathrm{g}$ (about $4 \mathrm{~mm} \mathrm{SL}$ ) to $0.18 \mathrm{~d}^{-1}$ for larvae at $\left.380 \mu \mathrm{g}(8 \mathrm{~mm} \mathrm{SL})\right]$. Our rates were somewhat higher than those predicted by Peterson \& Wroblewski's (1984) model of mortality rates for marine organisms.

Relatively small changes in growth and mortality rates could cause significant changes in recruitment, as suggested for Atlantic cod (Gadus morhua; Houde 1987). The low growth rates, which imply long stage duration, and relatively high mortality rates during the early ontogeny of walleye pollock indicate that fluctua- tions in recruitment may be controlled during the early larval stage.

Acknowledgements. This research was conducted as part of the Fisheries Oceanography Coordinated Investigations (NOAA, Seattle); we thank the members of this group for their help with field collections. We also thank N. Merati for laboratory help and R. Bates for computer assistance. S. Campana, A. Hollowed, A. Kendall, R. Methot, T Mulligan, S. Picquelle and 3 anonymous reviewers provided helpful comments on drafts of this manuscript.

\section{LITERATURE CITED}

Bailey, K. M., Stehr, C. L. (1986). Laboratory studies on the early life history of the walleye pollock, Theragra chalcogramma (Pallas). J. exp. mar. Biol. Ecol. 99: 233-246

Bailey, K. M., Stehr, C. L. (1988). The effects of feeding periodicity and ration on the rate of increment formation in otoliths of larval walleye pollock Theragra chalcogramma (Pallas). J. exp. mar. Biol. Ecol. 122: 147-161

Boehlert, G. W., Yoklavich, M. M. (1985). Larval and juvenile growth of sablefish, Anoplopoma fimbria, as determined from otolith increments. Fish. Bull. U.S. 83: 475-481

Campana, S. E., Gagne, J. A., Munro, J. (1987). Otolith microstructure of larval herring (Clupea harengus): image or reality. Can. J. Fish Aquat. Sci. 44: 1922-1929

Campana, S. E., Hurley, P. C. .F (1989). An age- and temperature-mediated growth model for cod (Gadus morhua) and haddock (Melanogrammus aeglefinus) larvae in the Gulf of Maine. Can. J. Fish Aquat. Sci. 46: 603-613

Campana, S. E., Neilson, J. D. (1985). Microstructure of fish otoliths. Can. J. Fish Aquat. Sci. 42: 1014-1032

Checkley, D. M., Jr, Raman, S., Maillet, G. L., Mason, K. M. (1988). Winter storm effects on the spawning and larval drift of a pelagic fish. Nature, Lond. $335: 346-348$

Cushing, D. H. (1975). Marine ecology and fisheries. Cambridge University Press, Cambridge

Dunn, J. R., Rugen, W. C. (1989). A catalog of Northwest and Alaska Fisheries Center ichthyoplankton cruises 1965-1988. NWAF C Processed Rep. 89-04. Alaska Fish. Sci. Cent., Seattle

Essig, R. J., Cole, C. F. (1986). Methods of estimating larval fish mortality from daily increments in otoliths. Trans. Am. Fish. Soc. 115: 34-40

Food and Agriculture Organization (1974). Catches and landings, 1973. Yearbook of Fishery Statistics 36, FAO, Rome

Food and Agriculture Organization. (1988). Catches and landings, 1986. Yearbook of Fishery Statistics 62, FAO, Rome

Gamble, J. C., Houde, E. D. (1984). Growth, mortality and feeding of cod (Gadus morhua L.) larvae in enclosed water columns and in laboratory tanks. In: Dahl, E., Danielssen, D. S., Moksness, E., Solemdal, P. (eds.). The propagation of cod Gadus morhua L. Institute of Marine Research, Flodevigen Biological Station, Flodevigen Rapportserie 1, Arendal, Norway, p. 123-143

Haynes, E. G., Ignell, S. E. (1983). Effect of temperature on rate of embryonic development of walleye pollock, Theragra chalcogramma. Fish. Buil. U.S. 81: 890-894

Hinckley, S., Bailey, K., Schumacher, J., Picquelle, S. Stabeno, P. (1989). Preliminary results of a survey for latestage larval walleye pollock and observations of larval drift in the western Gulf of Alaska, 1987. In: Proceedings of the international symposium on the biology and management 
of walleye pollock. Univ. of Alaska Sea Grant Rep. Ak-SG89-01, Fairbanks, p. 297-306

Houde, E. D. (1987). Fish early life dynamics and recruitment variability. Am. Fish. Soc. Symp. 2: 17-29

Incze, L. S., Kendall, A. W., Jr, Schumacher, J. D., Reed, R. K. (1989). Interactions of a mesoscale patch of larval fish (Theragra chalcogramma) with the Alaska Coastal Current. Contin. Shelf Res. 9: 269-284

Kendall, A. W., Jr, Clarke, M. E., Yoklavich, M. M., Boehlert, G. W. (1987). Distribution, feeding, and growth of larval walleye pollock, Theragra chalcogramma, from Shelikof Strait, Gulf of Alaska. Fish. Bull. U.S. 85: 499-521

Kim, S. (1987). Spawning behavior and early life history of walleye pollock, Theragra chalcogramma, in Shelikof Strait, Gulf of Alaska, in relation to oceanographic factors. Ph. D. dissertation, Univ. Washington, Seattle

Kimura, D. K. (1977). Statistical assessment of the age-length key. J. Fish. Res. Bd Can. 34: 317-324

McGurk, M. D. (1986). Natural mortality of marine pelagic fish eggs and larvae: role of spatial patchiness. Mar. Ecol. Prog. Ser. 34: 227-242

Megrey, B. A. (1989). Gulf of Alaska walleye pollock: population assessment and status of the resource as estimated in 1988. In: Wilderbuer, T. K. (ed.) Condition of groundfish resources in the Gulf of Alaska in 1988. NOAA Tech Memo U.S. Dep. Commerce NMFS F/NWC-165, p. 1-54

Methot, R. D., Jr (1983). Seasonal variation in survival of larval northem anchovy, Engraulis mordax, estimated from the age distribution of juveniles. Fish. Bull. U.S. 81: $741-750$

Methot, R. D., Jr (1986). Frame trawl for sampling pelagic juvenile fish. Calif. coop. ocean. Fish. Invest. Rep. 27: 267-278

Methot, R. D., Jr, Kramer, D. (1979). Growth of northern anchovy, Engraulis mordax, larvae in the sea. Fish. Bull. U.S. $77: 413-423$

Miller, T. J., Crowder, L. B., Rice, J. A., Marschall, E. A. (1988) Larval size and recruitment mechanisms in fishes: toward a conceptual framework. Can. J. Fish. Aquat. Sci. 45 $1657-1670$

Nishimura, A., Yamada, J. (1984). Age and growth of larval

This article was submitted to the editor and juvenile walleye pollock, Theragra chalcogramma (Pallas), as determined by otolith daily growth increments. J. exp. mar. Biol. Ecol. 82: 191-205

Nishimura, A., Yamada, J. (1988). Geographical differences in early growth of walleye pollock. Theragra chalcogramma, estimated by back-calculation of otolith daily growth increments. Mar. Biol. 97: 459-465

Nyman, R. M. Conover, D. O. (1988). The relation between spawning season and the recruitment of young-of-the-year bluefish, Pomatomus saltatrix, to New York. Fish. Bull. U.S. 86: $237-250$

Parrish, R. H., Nelson, C. S., Bakun, A. (1981). Transport mechanisms and reproductive success of fishes in the California current. Biol. Oceanogr (N.Y.) 1: 175-203

Peterson, I., Wroblewski, J. S. (1984). Mortality rate of fishes in the pelagic ecosystem. Can. J. Fish Aquat. Sci. 41: $1117-1120$

Reed, R. K., Incze, L. S., Schumacher, J. D. (1989). Estimation of the effects of flow on dispersion of larval pollock, Theragra chalcogramma, in Shelikof Strait, Alaska. Can. J. Fish. Aquat. Sci. Spec. Publ. 108: 280-294

Rice, J. A., Crowder, L. B., Holey, M. E. (1987). Exploration of mechanisms regulating larval survival in Lake Michigan bloater: a recruitment analysis based on characteristics of individual larvae. Trans. Am. Fish. Soc. 116: 703-718

Richardson, S. L. (1981). Spawning biomass and early life of northern anchovy, Engraulis mordax, in the northern subpopulation off Oregon and Washington. Fish. Bull U.S. 78 $855-876$

Shepherd, J. G., Cushing, D. H. (1980). A mechanism for density-dependent survival of larval fish as the basis of a stock-recruitment relationship. J. Cons. int. Explor. Mer 39: $160-167$

Warlen, S. M. (1988). Age and growth of larval gulf menhaden, Brevoortia patronus, in the northern Gulf of Mexico. Fish. Bull. U.S. 86: $77-90$

Wilkinson, L. (1987). Systat: the system for statistics. Systat, Inc., Evanston II

Yamashita, Y., Bailey, K. M. (1989). A laboratory study of the bioenergetics of larval walleye pollock, Theragra chalcogramma. Fish. Bull. U.S. 87: 525-536

Manuscript first received: October 16, 1989

Revised version accepted: March 9, 1990 